\title{
Improving Corporate Values Through The Size of Companies and Capital Structures
}

\author{
Windi Novianti \\ Management Departement \\ Universitas Komputer Indonesia \\ Bandung, Indonesia \\ windi.novianti@email.unikom.ac.id
}

\author{
Wendy May Agustian \\ Management Departement \\ Universitas Komputer Indonesia \\ Bandung, Indonesia \\ windi.novianti@email.unikom.ac.id
}

\begin{abstract}
The purpose of this study was to find evidence of whether the company's size and capital structure had an impact on the value of the company in food and beverage companies listed on the Indonesian Stock Exchange in the 2011-2015 period by taking samples of seven companies from 14 food and beverage companies listed on the Indonesian Stock Exchange. This research used descriptive and verification through a quantitative approach. The analysis design used was Multiple Linear Regression using secondary data, while hypothesis testing used were the T-Test and F-Test. The findings of this study were fluctuations in company size, capital structure and the value of companies experiencing fluctuations each year. Statistical analysis proves that firm size and capital structure had a significant effect on firm value simultaneously. While partial analysis shows that the size of the company had a significant effect on firm value, and capital structure had a significant effect on the value of the company.
\end{abstract}

Keyword-Company Size, Capital Structure, Company Value

\section{INTRODUCTION}

The main issue of this research is about the size of the company, the capital structure, and the value of the company. The main objective of the company is to increase the value of the company. The value of the company is used as a success measurement of the company's management in the prospects of future operations so that it can realize the trust for the shareholders of the company, because if the welfare of the shareholders is able to be fulfilled, then surely the situation reflects the high value of the company as well. Firm size is the differentianting factor to all other capital structure ratios. Capital Structure as: "a combination of equity and debt"[1]. Capital Structure has been one of the most controversial issues in the theory of finance during past 40 years [2]. Furhermore, capital structure is in prportion to the number of short term debt that is permanent, long term debt, preference shares and ordinary shares [3].

There are many factors that influence the value of the company, some of which are company size and capital structure.Research conducted shows that the capital structure partially has a significant positive effect on firm value in companies listed on the LQ 45 index [4]. The results of the analysis showed that the capital structure and firm size simultaneously had a positive and significant effect on firm value. While partially, the capital structure has a positive and significant effect on firm value and firm size has a positive and significant effect on firm value [5].

Capital structure has a positive influence on firm value. This shows that determining the company's capital structure is important, because it can optimize the value of the company. While variable company size does not have a significant positive effect on firm value. This shows that the size of the company influences investors' judgment in making investment decisions [6]. Research conducted that leverage has a significant influence on firm value. This is used for hotel owners in seeing their debts and fulfilling various goals in improving company quality and corporate debt by making better financial decisions [7]. Size influences the value of the company, while the capital structure measured by DER does not have a significant influence on the value of the company, still higher than the debt owned by the company [8].

\section{METHOD}

The research method used in this research was descriptive verification method with a quantitative approach. Quantitative method was used to test the effect of capital structure and company size on increasing the value of the company. The sample in this study was the report on the Size of Company Development (Capital), Structure of Capital (DER), and Company Value (PBV) at 7 food and beverage companies company. The design of quantitative analysis were the Multiple Regression Analysis, Correlation Coefficient Analysis, Determination Coefficient Analysis and Hypotheses Testing. Partial hypothesis testing used the T-test and hypothesis testing simultaneously through the F-test. Operationalizaton of variables can be seen in below :

\section{Exogeneous Variables (Independent variables):}

X1 (Company Size): Describes the size of the company. The size of the business was viewed from the business field that was being operated. The size of the company can be determined based on total sales, total assets, average sales level.

$$
\text { Size }=\text { Ln of total assets }
$$

X2 (Capital Structure): Balance between foreign capital or debt with own capital. 


$$
D E R=\frac{\text { Total Debt }}{\text { Equity }} \times 100 \%
$$

Endogeneous Variable (dependent variable)

$\mathrm{Y}$ (Firm Value) : The price that the prospective buyer is willing to pay if the company is sold, the higher the value of the company, the greater the prosperity that the owner of the company will receive.

Research Hypothesis

$$
\text { PBV }=\frac{\text { Market Price Per Share }}{\text { Book Value Per Share }} \times 100 \%
$$

H1 : The size of the company affected the value of the company

H2 : Capital structure affected the value of the company

H3 : Firm size and capital structure affected the value of the company

\section{RESUlTS AND DisCUSSION}

To prove that the effect of firm size and capital structure on firm value is carried out a series of tests by looking at the coefficient of variation $\left(\mathrm{R}^{2}\right)$ and $\mathrm{F}$ test. The empirical model of the estimation of firm size model, capital structure and firm value in food and beverage companies listed on the Indonesian Stock Exchange can be seen in the table 2 as follows.

\section{Results of testing company size}

TABLE I. RESULTS OF TESTING COMPANY SIZE HYPOTHESIS AND CAPITAL STRUCTURE AGAINST COMPANY VALUE

\begin{tabular}{|c|c|c|c|c|c|}
\hline $\begin{array}{c}\text { Indepen } \\
\mathbf{t} \\
\text { Variabl } \\
\text { es }\end{array}$ & $\begin{array}{c}\text { Expecte } \\
\mathbf{d} \text { Sign }\end{array}$ & $\begin{array}{c}\text { Coefficie } \\
\text { nt }\end{array}$ & $\begin{array}{c}\text { t_statisti } \\
\text { cs }\end{array}$ & Prob & Conclusions \\
\hline$C$ & & $-574,208$ & $-2,754$ & 0.010 & $\begin{array}{c}\text { Ho sign is } \\
\text { rejected on } \\
\alpha=0.05\end{array}$ \\
\hline $\begin{array}{c}\text { Compan } \\
\text { y Size }\end{array}$ & $(+) /(-)$ & 27,035 & 3,458 & 0.002 & $\begin{array}{c}\text { Ho sign is } \\
\text { rejected on } \\
\alpha=0.05\end{array}$ \\
\hline $\begin{array}{c}\text { Capital } \\
\text { Structure }\end{array}$ & $(+) /(-)$ & 2,071 & 3,345 & 0.002 & $\begin{array}{c}\text { Ho sign is } \\
\text { rejected on } \\
\alpha=0.05\end{array}$ \\
\hline $\begin{array}{c}F \text {-stat } \\
\text { Adjusted } \\
R^{2}\end{array}$ & $(+)$ & 19,336 & & 0.000 & $\begin{array}{c}\text { Ho sign is } \\
\text { rejected on } \\
\alpha=0.05\end{array}$ \\
\hline
\end{tabular}

Based on the equation model in Table 1.2, the value of adjusted $\mathrm{R}^{2}$ is 0.547 which means that 54.7 percent of the changes that occur in the endogenous variable (firm value) can be explained by exogenous variables namely firm size and capital structure. With the F-stat result of 19.336 probability value of 0.0000 , it can be concluded that the exogenous variables contained in the model can describe linear relationships with endogenous variables or in other words, firm size and capital structure simultaneously have a significant effect on firm value.

From the results of these calculations it can be seen that the value of the Company Size is 3.458 with a significant value of 0.002 . Because the value of tcount, 3.458 , is greater than $t$ table 2.037 then the error rate of $5 \%$ is decided to reject $\mathrm{H}_{0}$ so that $\mathrm{H}_{\mathrm{a}}$ is accepted. This means that with a $95 \%$ confidence level it can be concluded that the Company Size has a significant partial effect on the value of the company in food and beverage companies.

From the results of partial hypothesis testing ( $t$ test) above, the results of these tests support the opinions of the previous research journals entitled "Capital structure, company size and company risk to the value of automotive companies listed in IDX (Indonesian Stock Exchange) ", Company size is seen from the total assets owned by the company that can be used for the company's operations. If the company has large total assets, the management is more free to use the assets in the company. If viewed from the management side, the ease with which it controls the company will increase the value of the company [9].

"From testing the hypothesis it can be seen that the value of $t_{\text {count }}$ of Capital Structure variable is 3.345 with a significant value of 0.002 . Because the value of $t_{\text {count }} 3.345>t_{\text {table }} 2.037$ then the error rate of $5 \%$ is decided $\mathrm{H}_{0}$ is rejected. Company value in food and beverage companies From the results of partial hypothesis testing ( $t$ test) above, the test results support the opinions of previous research conducted by Karina and Titik (2016) entitled "The effect of size, growth, profitability, capital structure, policy dividends on company value ",Optimal capital structure can be interpreted as a capital structure that can minimize the cost of using overall capital so as to maximize the value of the company [10].

Based on simultaneous testing results, it is known that the $F_{\text {count }}$ value $(19,336)>F_{\text {table }}(3,295)$, so that $H_{o}$ is rejected, meaning that $\mathrm{F}_{\text {count }}$ is greater than $\mathrm{F}_{\text {table, }}$, which means company Size and capitalsStructure have a significant effect on company value in food and beverage companies [11]. The test results are the same as the results of previous studies entitled "The effect of firm size, institutional ownership, managerial ownership, profitability, capital structure on the value of manufacturing companies listed in LQ 45 for the period 20122014", mentions that company size and capital structure have a significant effect simultaneously on Company Value [12]

\section{CONCLUSION}

Company size affects the value of the company. The results of this study supports previous researches. Companies that are getting bigger can guarantee higher company value, because large companies will dare to expand, before their obligations are repaid. The capital structure also affects the value of the company and supports previous researches. The company will use funds from the inside to finance its operational activities. Thus, the risk of bankruptcy will be low, so investors will be attracted to companies that have a low risk of bankruptcy. This makes investors interested in buying shares in the company so that the stock price is high and increases the value of the company. Simultaneously, firm size and capital structure both affect the value of the company

\section{ACKNOWLEDGMENT}

The author would like to thank the Unikom Rector Dr. Ir. H. Eddy Soeryanto Soegoto., and Dean of the Faculty of Economics and Business Prof. Dr. Hj. Dwi Kartini Yahya., 
SE., Spec. Lic, who has given the opportunity to do this research.

\section{REFERENCES}

[1] Koralun, Julia.2017. How Does the Firm Affect the Relative Importance of Country and Industry Effect in Capital Structure. Empirical Evidence From Europe. Argument Oeconomica. ISSN 1233-5835

[2] Michael Njogu Wahome, Dr.F. Memba, Dr. Willy Muturi, 2015. The Effects of Firm Size and Risk on Capital Structure Decisions of Insurance Industri in Kenya. International Journal of Scientific and Research Publication, Volume5. ISSN 2250-3153.

[3] Hasbi Hamyat,2017. The Effect of Firm Size and Diversification on Capital Structure and Firm Value (Study in Manufacturing Sector in Indonesia Stock Exchange). The International Journal of Engineering abd Science(IJES). ISSN (e) :2319-1813

[4] Mawar Sharon R. Pantow, Sri Murni, Irvan Trang. 2015. Analisa Pertumbuhan Penjualan, Ukuran Perusahaan, Return On Asset, dan Struktur Modal Terhadap Nilai Perusahaan yang Tercatat di Indeks LQ 45. Jurnal EMBA, ISSN : 2303-1174 Vol.3 No.1 Maret 2015. Manado.

[5] Nenggar Bestariningrum. 2015. Analyzing The Effect of Capital Structure and Firm Size on Firm Value ( Case Study : Company That Listed in LQ-45 Index Period 2010-2014). Jurnal Berkala Ilmiah Efisiensi Volume 15 No.04 Tahun 2015. Manado.

[6] Didik Prabowo, Sunarto, Bambang Sudiyatno. 2016. Effects Capital Structure, Managerial Ownership, Firmsize, and Tangible Asset to The Firm Value:Empirical Studi on Indonesia Stock Exchange. Prosiding International Conference of Banking, Accounting, Management and Economics\&Call For Paper, ISBN : 978-979-3649-77-1. Magelang.

[7] Divya Aggarwal, Purna Chandra Padhan. 2017. Impact of Capital Structure on Firm Value : Evidence From Indian Hospitality Industry. Theoretical Economics Letters, ISSN Online : 2162-2086. India.

[8] Anung Dian Kosimpang, Rita Andini, Abrar Oemar. 2017. Pengaruh Profitabilitas, Ukuran Perusahaan terhadap Nilai Perusahaan dengan Variabel Struktur Modal sebagai Variabel Intervening pada Perusahaan Pertambangan yang terdaftar di BEI Periode Tahun 2012-2016. Jurnal Universitas Pandanaran. Semarang.

[9] Ta'dir Eko Prasetia, Parengkuan Tommy, Ivone S. Saerang. 2014 Struktur Modal, Ukuran Perusahaan, dan Risiko Perusahaan Terhadap Nilai Perusahaan Otomotif yang Terdaftar di BEI. Jurnal EMBA Universitas Sam Ratulangi Manado ISSN : 2303-1174 Vol.2 No.2 Juni 2014 hal.879-889, Manado.

[10] Karina Meidiawati, Titik Mildawati. 2016. Pengaruh Size, Growth, Profitabilitas, Struktur Modal, Kebijakan Dividen Terhadap Nilai Perusahaan. Jurnal Ilmu dan Riset Akuntansi, ISSN : 2460-0585 Volume 5 No.2 Februari 2016. Surabaya.

[11] Didy Handoko, 2016. The Influence of Firm Characteristics on Capital Structure and Firm Value : An Empirical Studi of Indonesia Insurance Companies. International Journal of Economics, Commerce and Management. ISSN 2348 0386. United Kingdom

[12] Azizah Amanda, Muhammad Firdaus. 2015. Pengaruh Firm-Size, Kepemilikan Institutional, Kepemilikan Manajerial, Profitabilitas, Struktur Modal terhadap Nilai Perusahaan Emiten Manufaktur yang terdaftar di LQ 45 periode 2012-2014. Prosiding PESAT Universitas Gunadarma, ISSN : 2302-8556 Vol.4 No.2 2013 Hal.358-372. Bali. 